\title{
Niet politici maar praktisch wijze professionals wijzen de weg naar fundamentele veranderingen
}

\author{
Sophie Albers*
}

\section{De praktijk}

Maya is wijkteamlid in een middelgrote stad in Nederland. Ze heeft de opdracht om burgers te helpen die een vraag hebben over ondersteuning, kinderen, inkomen en schuld. Op haar bureau komen de cases terecht die echt vastlopen.

Zoals de moeder die drie weken na de bevalling van haar kindje in 'civiele gijzeling' moest vanwege haar schulden. Dit betekent twee maanden in de gevangenis zitten als straf omdat je je schulden niet afbetaalt. En je kindje mag niet mee en belandt waarschijnlijk in de crisispleegzorg. En als ze eruit zou komen? Dan zouden naast een vreselijke kraamtijd haar schulden alleen maar zijn opgelopen. Maya stak daar een stokje voor door de schuld zo snel mogelijk af te kopen.

Maar ook de ex-verslaafde meneer die hard werkt om zijn leven weer op de rit te krijgen. En waarvan de rechter heeft gezegd dat hij weer voor zijn kinderen mag zorgen. Maar niet zolang hij in zijn auto woont. Hij moet dus een huis regelen. En oh ja, wel binnen zes maanden, anders zijn de kinderen zo gehecht aan hun pleegouders dat het niet wenselijk is om terug te gaan. Een huis vinden is heel moeilijk, voor sociale huurwoningen is een wachtlijst van acht jaar. En in je auto wonen is niet urgent genoeg om voorrang te krijgen. Want zo kreeg hij te horen: 'Straks gaan we allemaal in onze auto wonen om een huis te krijgen!' Maya vond een particuliere huurwoning en sloot een deal om garant te staan voor een deel van de huur.

Maya houdt van haar werk, ondanks dat het niet gemakkelijk is. 'Ik vind het zo pijnlijk om te zien dat het systeem waar ik voor werk vaak zelf de problemen veroorzaakt of erger maakt.' Niet zelden komt ze dan ook lijnrecht tegenover haar eigen collega's te staan. 'Ik moet vastbijten als een pitbull en soms ook wat in het donker opereren.' Maar als het haar lukt, is ze trots en blij en gelooft ze weer dat het allemaal beter kan worden.

\section{In het donker}

Het voorbeeld van Maya staat niet op zich. Er zijn duizenden professionals zoals zij dagelijks bezig het goede te doen voor de burgers die vastlopen in de bureaucratie. Denk aan wijkbeheerders, agenten, leerplichtambtenaren, reclasseringsambtenaren, jongerenwerkers, arbeidsconsulenten. Een opmerkelijke constatering: aan de ene kant zien we professionals alles op alles zetten om mensen goed te helpen en

* Sophie Albers, MA is actieonderzoeker bij het Instituut voor Publieke Waarden. 
aan de andere zien we een sociale crisis voor onze ogen ontvouwen. We zijn de menselijke maat verloren op veel terreinen. Niet alleen op het gebied van toeslagen, maar ook op zaken als schulden, wonen, jeugdzorg, rechtsbijstand moeten we constateren dat er weinig oog meer is voor het individu met zijn of haar eigen context.

Verklaringen die vaak genoemd zijn, zijn enerzijds het New Public Management als dominante bestuursstijl en anderzijds de bewuste politieke keuzes die hebben geleid tot bezuinigingen en schaarste. Aan analyses en verklaringen geen gebrek. Hendrik Noten noemt er ook verschillende in zijn bijdrage.

Wellicht intrigerender is het feit dat ondanks alles er dagelijks wordt gewerkt om de menselijke maat te herstellen. Maar dat gebeurt 'in het donker', zoals Maya dat noemt. Het valt niemand op. Juist daar kunnen we de fundamentele oplossingen vinden waar Noten om vraagt. Niet zozeer in Den Haag. Wat doen Maya en haar collega's dan precies? En welk oplossingspotentieel hebben we hiermee in handen?

\section{Praktische wijsheid}

Wat Maya doet voor de mensen die ze helpt, zou Aristoteles praktische wijsheid noemen. Aristoteles stelt dat in situaties waarin we niet weten wat we moeten doen, we moeten handelen. Alleen door te handelen leren we wat het goede is. Dat goede omschrijft hij als het juiste midden tussen twee uitersten. Zo ligt moed tussen lafheid en overmoed. Praktische wijsheid, de kennis die vervat ligt in de handeling, zet hij af tegen technische kennis, kennis die wordt vergaard door ratio. Het beoefenen van praktische wijsheid is niet zonder risico. Je zet jezelf ermee op het spel, want het kan helemaal misgaan. Daarom noemt Aristoteles dit ook de hoogste vorm van kennis. Omdat het heel moeilijk en spannend is om hem te bemachtigen.

Maya handelt ook. Dit is voor haar de enige manier om mensen te helpen. Ze zoekt daarbij ook continu naar het juiste midden tussen regels en ruimte. Slaat ze door en volgt ze slechts de regels, dan zou ze niet verder komen. Maar er is ook het risico van te veel ruimte pakken en alle problemen van mensen op haar schouders nemen. Dan wordt ze door het systeem niet meer serieus genomen en komt ze uiteindelijk met een burn-out thuis te zitten. Ze zoekt het juiste midden door nou juist slim gebruik te maken van zowel regels als ruimte. Zoals vele publieke professionals in Nederland.

Aan de praktische wijsheid van publieke professionals kleeft een groot probleem: het is volstrekt onzichtbaar. Enerzijds komt dit doordat praktisch wijze professionals wat ze zelf doen niet bijster bijzonder vinden: 'Da's toch logisch?!' En dus hangen ze het niet aan de grote klok. Anderzijds maakt de wijze waarop we het publieke stelsel hebben ingericht ons er blind voor. Verkokering in financiering en wetgeving maakt dat we de 'holistische' oplossingen van Maya niet in hun totaliteit kunnen zien. Bovendien staat de publieke professional in de top-down inrichting van het stelsel aan het einde van de keten. Maya is slechts uitvoerder van beleid. Ze wordt niet gezien als kennisbron. 


\section{Niet denken, maar doen}

Hendrik Noten pleit voor de introductie van drie nieuwe waarden binnen de overheid. Waarden die de kloof tussen burger en staat moeten dichten. Waarden die we moeten organiseren. De neiging ontstaat om hier een nieuwe blauwdruk voor het stelsel op te ontwikkelen. Maar het risico bestaat dat dit ook weer nieuwe onnavolgbare bureaucratie oplevert. Laten we Aristoteles meer ter harte nemen en al handelend erachter komen wat goed is.

Maya en haar praktisch wijze collega's kunnen de voedingsbron voor het ontwikkelen van de waardegedreven overheid zijn. Van hun praktische wijsheid kunnen we leren waar beleid onbedoelde effecten sorteert, waar uitsluiting ontstaat, maar ook hoe het systeem recht kan doen aan de burger. Zie praktisch wijze professionals als een research en development-team. Zij proberen in het klein dingen uit die bij succes structureel opgepakt worden. Zoals Herman Tjeenk Willink zegt: Groter denken, kleiner doen.

Een suggestie voor het nieuwe kabinet is dan ook om een Raad van Praktische Wijzen in te richten die de overheid gevraagd en ongevraagd kan adviseren over het realiseren van de menselijke maat. Zo kunnen kabinet en Tweede Kamer een beroep doen op de kennisbron die ontstaat in het handelen. Het ontwikkelen van een waardegedreven overheid begint met het inrichten van een bottom-up permanent lerende overheid.

Overigens mocht Maya onlangs op bezoek komen bij een Tweede Kamer-commissie die het herstellen van de menselijke maat onderzocht. De commissieleden hoorden haar uit over de problemen die ze ziet, maar ook over de oplossingskansen. 'Het was een mooi gesprek en we verwachten binnenkort weer op de koffie te komen!' De eerste stap is gezet. 